\title{
Public Housing in the Global Cities: Hong Kong and Singapore at the Crossroads
}

\author{
Anutosh Das ${ }^{1,2}$ \\ ${ }^{1}$ Department of Urban Planning and Design, The University of Hong Kong (HKU), Hong Kong \\ ${ }^{2}$ Department of Urban \& Regional Planning, Rajshahi University of Engineering \& Technology (RUET), Rajshahi, Bangladesh
}

\section{Email address:}

anutosh@hku.hk, anutosh@urp.ruet.ac.bd

\section{To cite this article:}

Anutosh Das. Public Housing in the Global Cities: Hong Kong and Singapore at the Crossroads. Urban and Regional Planning. Vol. 6, No. 1, 2021, pp. 41-46. doi: 10.11648/j.urp.20210601.14

Received: September 11, 2020; Accepted: February 9, 2021; Published: February 20, 2021

\begin{abstract}
Affordable Housing, the basic human necessity has now become a critical problem in global cities with direct impacts on people's well-being. While a well-functioning housing market may augment the economic efficiency and productivity of a city, it may trigger housing affordability issues leading crucial economic and political crises side by side if not handled properly. In global cities e.g. Singapore and Hong Kong where affordable housing for all has become one of the greatest concerns of the Government, this issue can be tackled capably by the provision of public housing. In Singapore, nearly $90 \%$ of the total population lives in public housing including public rental and subsidized ownership, whereas the figure tally only about $45 \%$ in Hong Kong. Hence this study is an effort to scrutinizing the key drivers of success in affordable public housing through following a qualitative case study based research methodological approach to present successful experience and insight from different socio-economic and geo-political context. As a major intervention, this research has clinched that, housing affordability should be backed up by demand-side policies aiming to help occupants and proprietors to grow financial capacity e.g. subsidized rental and subsidized ownership can be an integral part of the public housing system to improve housing affordability.
\end{abstract}

Keywords: Public Housing, Housing Affordability, Global Cities, Subsidized Ownership, Demand-Side Policies, Social-Welfare

\section{The Tale of Two Cities: Public Housing in Hong Kong \& Singapore}

The two cities, Hong Kong and Singapore most often compared for their socio-economic condition and housing development. Both cities, although located nearly 2500 kilometers apart in the western Pacific Rim, are widely recognized and paralleled for their associated prompt and widespread socio-economic development as well as demographic condition, geographic location and so on (Figure 1). However, the stories of housing markets and housing affordability are quite different in the two nations. Therefore, this section will look diligently into the major socio-economic development indicators of the two cities, followed by the comparative understandings of their public housing policies and highlighting the key drivers contributing to the different outcomes.

According to the $15^{\text {th }}$ Demographia International Housing Affordability Survey 2019, Hong Kong showcases the least affordable and most expensive housing market with a median multiple of 20.9 with unending to widen the gap with the rest 92 major housing markets throughout the world. Whereas Singapore seems to offer a better housing option for their people with a median multiple of only 4.6 (Figure 2 and 3). The Median Multiple; also called housing affordability multiple, recommended by the United Nation (UN) and World Bank is widely used to compare housing affordability and housing market. It simply refers to the house price to gross income ratio of a person in a housing market $[1,2]$. 


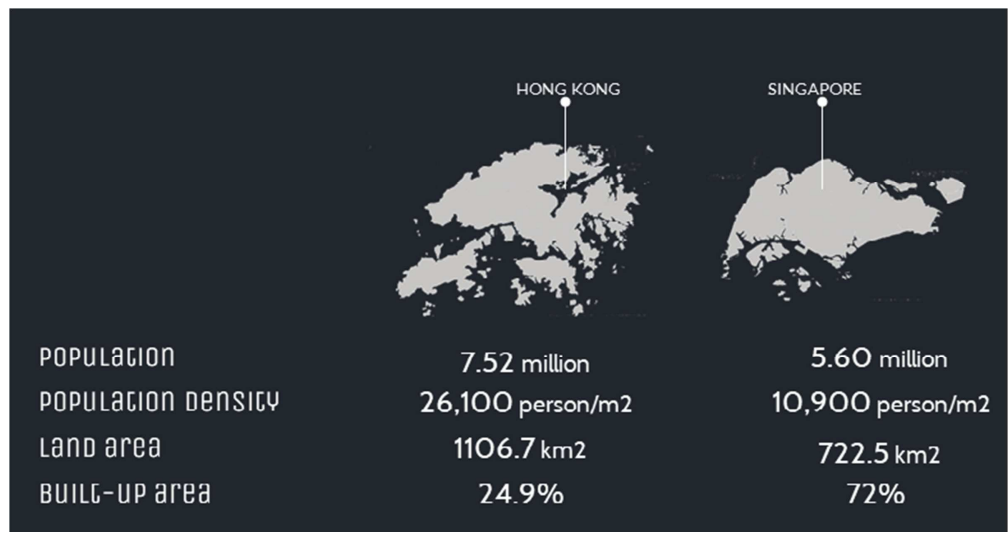

(Source: Author, 2020)

Figure 1. The paralleled condition in Hong Kong and Singapore-Equivalence \& Comparison.

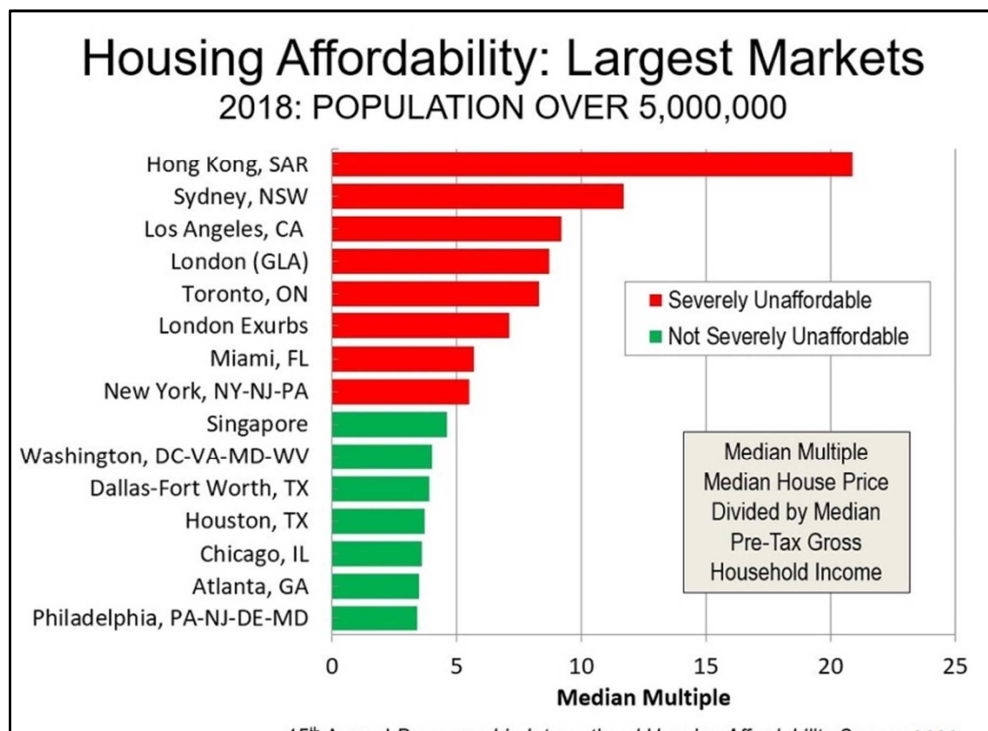

$15^{\text {th }}$ Annual Demographia International Housing Affordability Survey, 2019

Figure 2. 15 th Annual International Housing Affordability Survey Report, 2019.

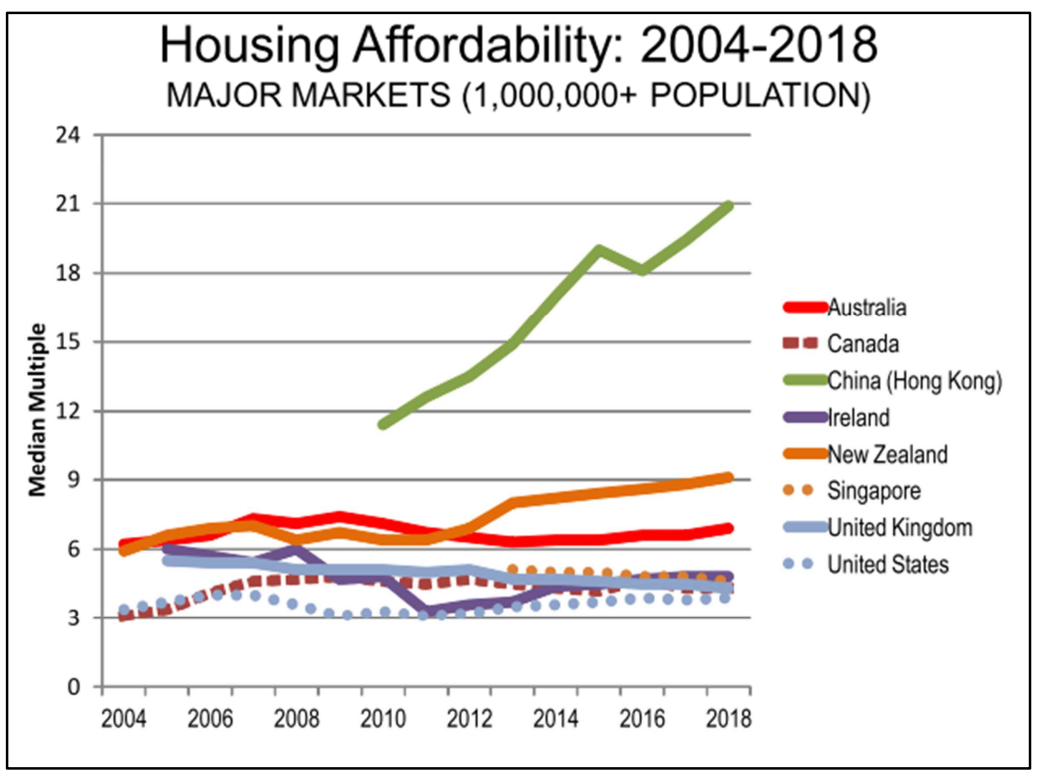

Source: [1]

Figure 3. Least Affordable Housing Market, 2019. 
Provision of affordable housing has a direct impact on the well-being of the people and society as well. If handle carefully, It can enhance a city's economic productivity. But on the contrary, it may result in a growing economic and political crisis if the housing market proves inefficient to meet peoples demand. Affordable housing is always a challenge for Asia's two giant economies: Hong Kong and
Singapore. As per CBRE's Fifth "Global Living" report, Hong Kong is the most expensive city in the world to live. An average property price in Hong Kong in 2019 is about the US \$ 1.234 million or about HK\$ 9.6 million whereas the US $\$ 874,000$ in Singapore with the second ranking $[3,4]$. The following table (Table 1) summarizes the key economic and social indicators of Hong Kong and Singapore.

Table 1. Key Economic and Social Indicators of Hong Kong and Singapore (2019).

\begin{tabular}{lll}
\hline & Hong Kong & Singapore \\
\hline Population & 7.52 million & 5.60 million \\
Land area & 1106.7 sq. kilometers & 722.5 sq. kilometers \\
Built-Up Area (\%) & 24.9 (Only 7\% for Housing) & 72 \\
Population Growth Rate & 1 & 2.4 \\
Real Growth in GDP (\%) & 2.6 & 4.7 \\
Per Capita GNI (US\$) & 51125 & 81,222 \\
Unemployment Rate (\%) & 2.9 & 2.9 \\
Inflation Rate (\%) & 3.2 & 1.33 \\
Home Ownership (\%) & 49.2 & 91 \\
Public Housing (\%) & 44.7 & 87 \\
Living Space Per Capita & 12.9 (sq. m) & $19-32$ (Depending Upon Flat Type) \\
\hline
\end{tabular}

(Source: Adapted from Census and Statistics Department, the Government of the HKSAR, 2019; Department of Statistics Singapore, Singapore in Figures 2019) [3, 4]

\section{Housing Policy in Singapore and Hong Kong: A Comparative Understanding}

The Housing Department of the Hong Kong Housing Authority (HKHA), manages and executes the public housing provision in Hong Kong. It is a statutory organization in
Hong Kong to develop and implement the public housing program. The HKHA is financed from different sources i.e., capital and indirect subsidies of land, the government budget and other incomes including sales and rental of properties, investment and premium income [5]. Table 2 summarizes a comparative understanding of the housing policies in Hong Kong and Singapore.

Table 2. Comparative Understanding of the Housing Policies in Singapore and Hong Kong.

\begin{tabular}{lll}
\hline & HONG KONG & SINGAPORE \\
\hline Social-welfare policy & Cash-Based Welfare Model (Indirect Subsidy) & Asset-Based Welfare Model (Proving Property Right). \\
Housing Policy & Dominating Private Land Market & State Dominated. \\
Eligibility & Strict income and asset restriction & More relaxed income and asset ceiling. Can Sell their Flats. \\
Supply of land & Strict Land Supply & More Flexible or "Elastic" land and housing supply. \\
Prioritization of the Need & $\begin{array}{l}\text { Allocate the limited housing resources only to } \\
\text { those in need. }\end{array}$ & Consider as Basic Right for all Citizen \\
Statutory Organization & The Housing Department of the Hong Kong & The Housing and Development Board (HDB) \\
State-Managed Social Security Fund & $\begin{array}{l}\text { Housing Authority (HKHA) } \\
\text { Avg. Waiting time for HOS }\end{array}$ & $\begin{array}{l}\text { Mandatory Provident Fund (MPF) } \\
\text { 4.7 years }\end{array}$ \\
\hline
\end{tabular}

Source: $[2,6-8]$

Singapore somehow follows the same generalized principle for public housing as Hong Kong. The Housing and Development Board (HDB), a statutory organization for public housing in Singapore, primarily responsible for planning and developing public housing provision. The core source of funding is also government budget and some other income including the income from rent, sale and investment in property as Hong Kong. The main difference is a statemanaged Central Provident Fund (CPF) for ensuring social security to the working population. The CPF, a form of forced savings for housing, retirement, health and education is integrated with the pension system to enhance the efficiency of savings. Despite relying on taxation, the government of Singapore uses the CPF fund for public housing development and ensures economic viability in the society through circulating back the money when people purchase public housing from HBD using their CPF $[9,10]$.

\section{Public Housing in Singapore: A Success Story}

Singapore has undergone a massive transformation since liberation, primarily in its economic strategy focusing modernization of the economy. Eventually, its results into massive success in public housing despite a large population in a limited area. But overcoming these constraints, this city has demonstrated remarkable success in its public housing domain primarily due to its more flexible or "elastic" land and housing supply with concentrated state influence. The 
government provides a wide range of grants and schemes to assist people in public homeownership. In terms of eligibility and sells permission of the purchased flats, the Singaporean Government is more flexible. In Singapore, the Housing and Development Board HDB provides nearly $80 \%$ of the total housing stock including subsidized ownership and public rental with ensuring minimum waiting time for getting the public flats [7, 11, 12]. Existing housing provision in Singapore is exhibited in Figure 4 in a nutshell.

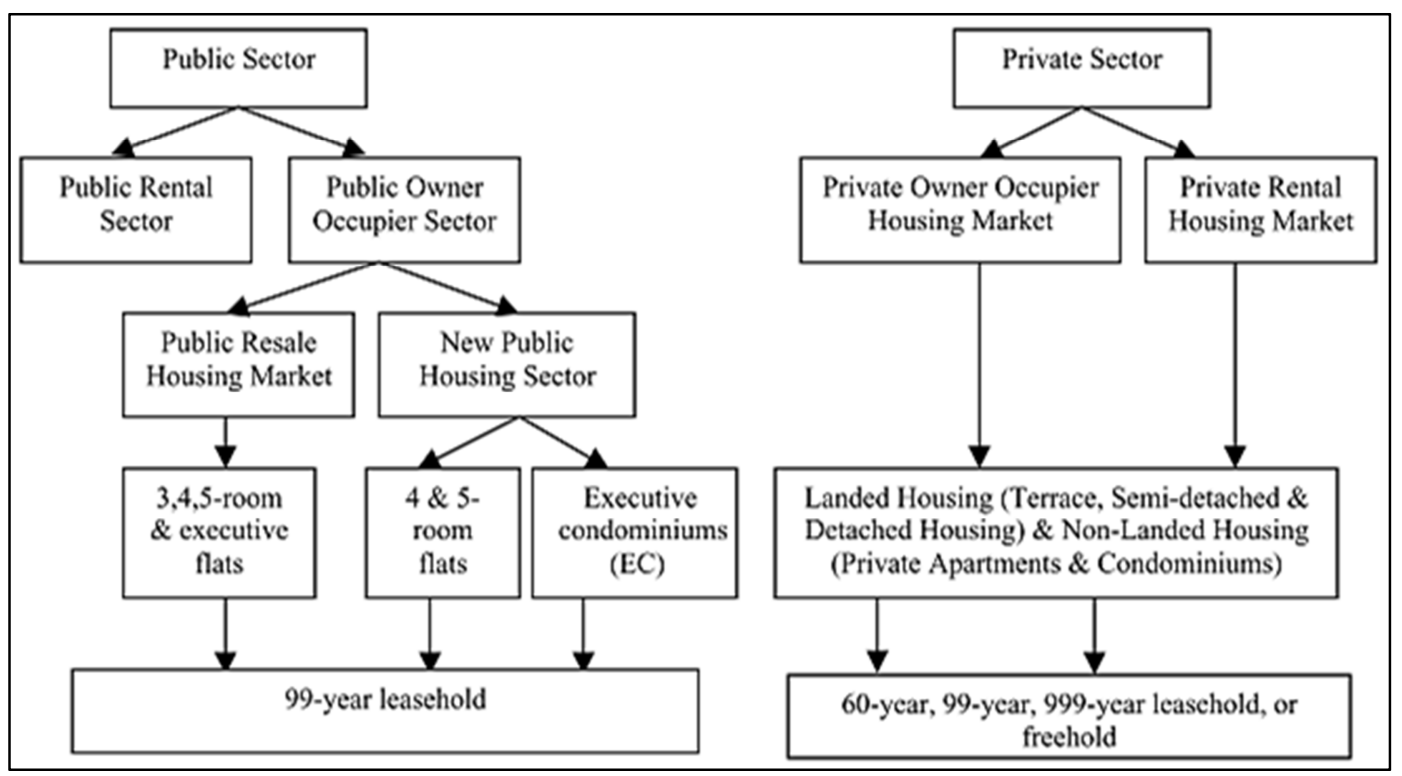

Source: [11]

Figure 4. Existing Housing Provision in Singapore.

\section{Key Factors Contributing to the Success of Public Housing Policies in Singapore}

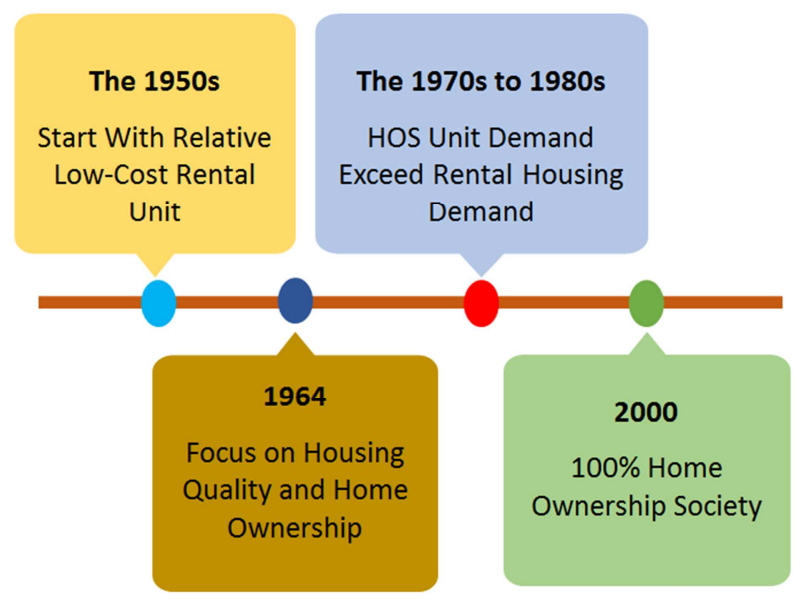

(Source: Author, 2020)

Figure 5. The Evolution of HOS Scheme in Singapore.

The public housing program in Singapore started with an aim to provide comparatively low-cost housing to the people. Since 1964, more emphasis was given on housing quality and homeownership with a national goal of achieving a full homeownership society by the end of this century, 2000. During the 1970s and 1980s, the homeownership demand exceeded far the rental housing. Eventually, major government interventions, especially during the 1970 s to 2000s, carried remarkable success in the Home Ownership Scheme (HOS) as well as public housing in Singapore. Figure 5 recapitulates the evolution of HOS Scheme in Singapore.

At presents, around $90 \%$ of Singapore's residents have their own homes. Several factors triggered the success of the government in Public housing provision i.e., a) Land Acquisition Policies of the Government, b) The Housing Finance System, c) Strong Political Commitment and Efficient Administration [8, 13].

\subsection{Land Acquisition Policies of the Government}

The Singapore Government focuses on the effective implementation and enforcement of compulsory land acquisition policies. The Land Acquisition Ordinance, 1920 was first enacted to enable the Singapore government to acquire private land for public purposes. Then the Land Acquisition Act of 1966, after Singapore's full independence in 1965, have empowered the government and its agencies, i.e. the HDB, to compulsorily acquire any private land needed for its development at prices well below the private land market. In public housing development in Singapore, this Act has been proved as a very powerful instrument. Government considers the land policies as a forceful means of redistributing wealth and resources to the society.

\subsection{Housing Finance System}

The availability of sufficient funds for public housing 
development from government tax revenue and the Central Provident Fund (CPF) is a major intervention for government success which was made possible by a major policy intervention in 1968. For CPF, both employers and employees need to contribute a certain percentage of their monthly salary. The HBD provides loan with a minimum interest rate to the people to assist in homeownership with a repayment period of maximum 25 years. Following an "Asset Based Welfare Model", the government subsidizes people to build up assets in the long run.

\subsection{Strong Political Commitment and Efficient Administration}

Public housing in Singapore is not just a social welfare program but for achieving the goal of a full property-owning society. This is also used politically by the Government to rally the support of its citizen through balancing the demand and supply side for housing following economic viability. The Housing and Development Board (HDB) was established as a Statutory Board to plan, build, and manage all public housing estates in 1960. The strong political support and institutional commitments are important ingredients for the HDB's efficient implementation and management of such a large-scale public housing program. Extensive legislative powers of the HDB and the allocation of huge financial, land and human resources for the public housing program make the HOS success indeed.

In a nutshell, several key factors as exhibited in Figure 6 but have contributed toward the ground-breaking success of public housing provision in Singapore as compared to Hong Kong.

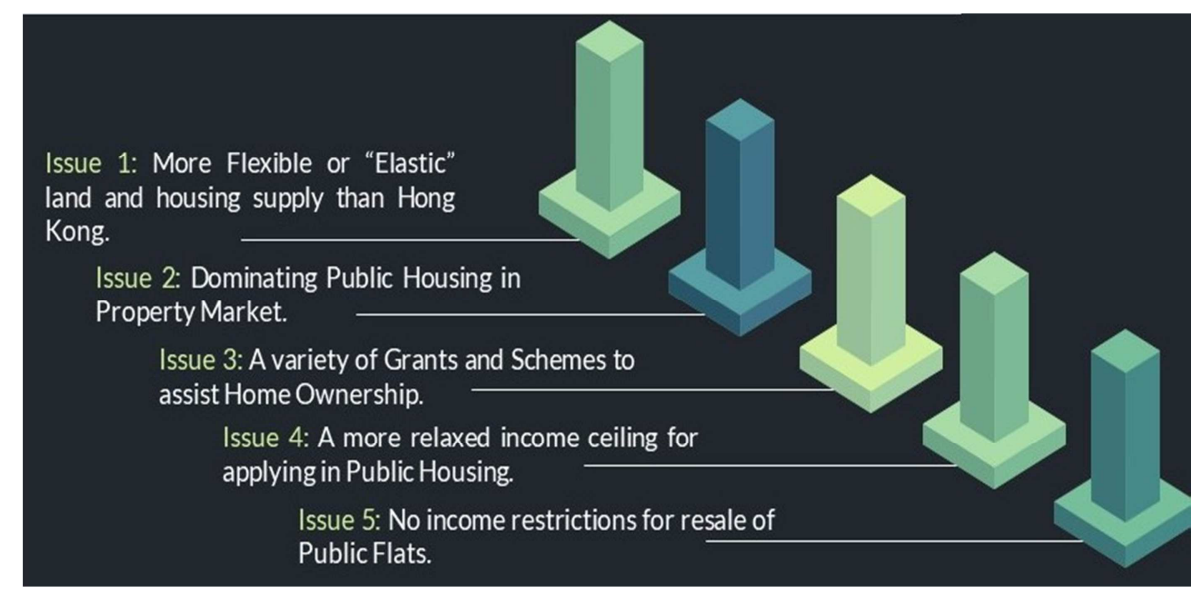

(Source: Author, 2020)

Figure 6. Key Factors Contributing to the Success of Public Housing in Singapore.

\section{Concluding Remark}

To summarize, the tactics on which Singapore Primarily Relies for Efficient Public Housing i.e., Compulsory Savings designed as a savings and payments institution, State Land Ownership and state provision of housing, Efficient Functionality Capability of the HBD in complex Resettlement, Town Planning, and Estate Management [2, 11, 15]. But the overwhelming success of Singapore public housing provision can easily spawn widespread inefficiency and corruption if not handled carefully. So the before transfer Singapore's experience to other countries, efficient juxtaposition needed with the local political and social context especially focusing housing finance system, land acquisition policies and political commitments as well as efficient administration system.

\section{References}

[1] Bertaud, A. (2019), “15th Annual Demographia International Housing Affordability Survey", http://www.demographia.com/ dhi.pdf, (last accessed on 13 November 2019).

[2] Zhang, R. J. (2017), "A Tale of Two Cities Comparative Study of Public Housing Policies", International Immersion
Program Papers (71).

[3] CBRE (2019), "Fifth Annual Global Living Report", https://www.cbreresidential.com/uk/en-GB/content/globalliving-2019, (last accessed on 10 November 2019).

[4] Census and Statistics Department, The Government of the HKSAR. (2019), Hong Kong Statistics, https://www.censtatd.gov.hk/hkstat/hkif/index.jsp, (last accessed on 15 November 2019).

[5] The Hong Kong Housing Authority (2018), Annual Report 2014/2015. Hong Kong, https://www.hkhs.com/home/ pdf/ar2018/index.html, (last accessed on 14 November 2019).

[6] Chua, B. H. (2014), "Navigating between limits: the future of public housing in Singapore", Housing Studies, 29(4), pp. 520-533.

[7] Fong, K.-w. P. (1989). A comparative study of public housing policies in Hong Kong and Singapore: Hong Kong.

[8] Fan, Y., \& Lin, G. (2019), “Affordable housing lessons from Sydney, Hong Kong and Singapore_ 3 keys to getting the policy mix right" The Conversation, pp. 1-5.

[9] Housing and Development Board (2019), Annual Report 2018/2019. Singapore, https://www20.hdb.gov.sg/fi10/ fi10221 p.nsf/hdb/2019/index.html, (last accessed on 15 November 2019). 
[10] Bardhan, A. D., Datta, R., Edelstein, R. H., \& Kim, L. S. (2003). A tale of two sectors: Upward mobility and the private housing market in Singapore. Journal of Housing Economics, $12(2), 83-105$.

[11] Yuen, B., KWEE, L. K., \& Tu, Y. (2006). Housing affordability in Singapore: can we move from public to private housing? Urban Policy and Research, 24(2), 253-270.

[12] Field, B. (1987), "Public housing in Singapore", Land Use Policy, 4(2), pp. 147-156.

[13] Chin, T., \& Strand, J. B. (2008). "Hong Kong vs. Singapore: A comparison of two real estate markets", Cornell Real Estate Review, 6, pp. 26-36.

[14] Department of Statistics Singapore. (2019), Singapore in Figures 2019, https://www.singstat.gov.sg//media/files/publications/situation/sif2019.pdf, (last accessed on 14 November 2019).

[15] Phang, S. Y. (2007), "The Singapore model of housing and the welfare state", Housing and the New Welfare State: Perspectives from East Asia and Europe, pp. 15-44, https://ink.library.smu.edu.sg/soe_research/596, (last accessed on 18 November 2019). 